\title{
Perceived Social Norms and Agripreneurial Intention among Youths in Eastern DRC
}

\author{
Akilimali Ndatabaye Ephrem ${ }^{1, *(\mathbb{D})}$, Paul Martin Dontsop Nguezet ${ }^{2} \mathbb{D}$, McEdward Murimbika $^{3} \mathbb{D}$, \\ Zoumana Bamba ${ }^{4}$ and Victor Manyong ${ }^{5}$
}

Citation: Ephrem, A.N.; Nguezet, P.M.D.; Murimbika, M.; Bamba, Z.; Manyong, V. Perceived Social Norms and Agripreneurial Intention among Youths in Eastern DRC. Sustainability 2021, 13, 3442. https://doi.org/ $10.3390 /$ su13063442

Academic Editor: María de la Cruz del Río-Rama

Received: 23 January 2021

Accepted: 8 March 2021

Published: 19 March 2021

Publisher's Note: MDPI stays neutral with regard to jurisdictional claims in published maps and institutional affiliations.

Copyright: (c) 2021 by the authors. Licensee MDPI, Basel, Switzerland. This article is an open access article distributed under the terms and conditions of the Creative Commons Attribution (CC BY) license (https:/ / creativecommons.org/licenses/by/ $4.0 /)$.
1 Faculty of Economics and Management, Université Officielle de Bukavu, Bukavu 570, Democratic Republic of the Congo

2 Social Science and Agribusiness, International Institute of Tropical Agriculture, Kalemie 570, Democratic Republic of the Congo; p.dontsop@cgiar.org

3 Graduate School of Business Administration, University of the Witwatesrand, Johannesburg 2050, South Africa; mcedward.murimbika@wits.ac.za

4 Capacity Development Unit, International Institute of Tropical Agriculture, Kinshasha 4163, Democratic Republic of the Congo; z.bamba@cgiar.org

5 Social Science and Agribusiness, International Institute of Tropical Agriculture, Daar Es Salaam 34441, Tanzania; v.manyong@cgiar.org

* Correspondence: akilimaliephrem@gmail.com; Tel.: +243844476468

\begin{abstract}
The Democratic Republic of the Congo (DRC) is a country with a high agricultural productivity potential; however, the agribusiness sector remains unattractive to youths. This study examined the extent to which perceived social norms and psychological capital affect youths' intentions to pursue agribusiness opportunities in the Eastern DRC. Data was collected on a sample of 600 youths. We applied Partial Least Squares Structural Equation Modelling (PLS-SEM) in order to examine the relationship between the variables. The findings indicated that most of the youths did not select agribusiness as their top career choice. The intention to engage in agribusiness activities was significantly higher among the youths who perceived that agribusiness was socially valued and supported. Psychological capital significantly and positively affects youths' agripreneurial intention. The findings contribute to the underlying Theory of Planned Behavior by supporting a positive mediation role of psychological capital - and the moderating roles of educational level, gender, access to land, and location - on the relationship between perceived social norms and agripreneurial intention. The paper concludes that the provision of funds is not enough to promote youth agripreneurship in an environment in which agricultural-related social norms, youths' psychological capital, gender, access to land, educational level, and location (rural versus urban) are not thoroughly considered.
\end{abstract}

Keywords: social norms; psychological capital; intention; agribusiness; TPB; youth

\section{Introduction}

Agribusiness has the potential to drive sustainable, inclusive, and diversified growth, which can address a wide array of challenges such as poverty, food shortages, hunger, and youth unemployment [1-6]. The DRC is the second-largest country in Africa by land, and the seventh and second globally in terms of arable land and the unused agricultural potential of the land capacity, respectively [2,7]. However, the majority of the youths have stayed out of the agribusiness and agricultural-related activities $[2,7,8]$. The decline in youth participation in the sector coupled with escalated rural to urban migration is increasingly reducing the capacity of the sector to be competitive at a global scale and to contribute to economic growth $[9,10]$. Youths represent up to $50 \%$ of the active population; however, they are three and a half times more likely to be unemployed than the remaining population $[9,11,12]$. In the eastern part of the country, only $1.1 \%$ of graduates are annually employed out of the thousands who complete their undergraduate studies each year in 
all fields [10]. The convergence of these facts prompted us to examine the factors that influence agripreneurial intention among youths.

There is significant empirical research exploring the construct of entrepreneurial intention (EI), which is often equal to or driven by entrepreneurial desirability [13-16]. The growth in EI-related research has been driven by the fact that EI has often been reported to be a strong predictor of opportunity discovery, development, and subsequent business creation [17-22].

However, most of existing research was based on developed economies [17-19], while a limited amount of empirical research has been carried out in Africa [16].

Generally, little is known about youth agripreneurial intention (AI) despite the effort of most Governments to attempt to engage the youth in the agricultural value chain. AI could be defined as the individual's interest and willingness to pursue business opportunities in agriculture and agri-related activities in the value chain [23-26]. We examined AI as the starting point to engage youths in agribusiness because the career choice is often volitional, conscious, and driven by cognitive mechanisms [24,27]. As such, the study applied the theory of planned behavior (TPB) to argue that youth engagement in agripreneurship is a planned process significantly influenced by the individual's psychological and social norm factors that regulate intention [13,28-35]. The basic idea behind the TPB is that the intention to engage in any endeavor is driven by three factors. These include selfconfidence in one's skills to perform the behavior (perceived behavioral control), the perception that the behavior is worth the pursuit (attitude), and the perception that the people and organizations around the individual will value and support the behavior (subjective norms or social norms) [15,28].

Against this background, this study examined the extent to which perceived social norms (PSN) and psychological capital (PC) affect youth intention to pursue agribusiness opportunities in the Eastern DRC. This study was a response to the extant literature that has called for the design and implementation of future interventions to engage youths in agribusiness, based on an integrated approach which considers the diversity of youth aspirations, perceptions, capabilities, and socio-cultural background $[2,6]$.

The paper argues that, when the social beliefs and values regarding agribusiness are favorable, the youth would expect that his/her decision to consider opportunities in the agricultural value chain will be socially valued and supported [36,37]. Such a perception would enhance youths' PC and the subsequent commitment to engage in agribusiness activities. PC is indeed subject to the environment in how it influences entrepreneurial career choices and outcomes [14,38-42]. Therefore, this paper hypothesizes that while PSN might directly influence the intention to engage in agribusiness, its effect is stronger when it channels through PC. More than any other business sector, agriculture is characterized by uncertainty and higher-risk exposure [43], implying that a potential agripreneur should have a higher PC to overcome the potentially high risks and drawbacks. Within the scope of this research, PC is a positive state of mind formed of perceived self-confidence, optimism, hope, and resilience [38] regarding the agribusiness career.

Thus, the specific objectives for this study were: (1) to examine the intention of youths to engage in any kinds of agribusiness activities, (2) to determine the effect of PSN and PC on the AI, (3) to assess the mediating role of PC, and (4) to assess the moderating roles of gender, educational level, location, and access to funds and land in the relationship between PSN and AI.

The study made two major contributions. First, the results revealed that the provision of funds is not enough to promote youth agribusiness if youths' perceptions of social norms about agribusiness, their PC, educational level, and location (rural versus urban) are not thoroughly considered. Second, the study contributes to the TPB by showing that the direct effect of PSN on AI is incomplete unless we account for the mediation role of PC and the moderating roles of youth location, gender, access to land, and educational level.

The rest of the paper is organized as follows. The next section is a review of the literature. Then, the methodology is presented, and is followed by the results section. The 
main findings are then discussed by highlighting the important theoretical, methodological, and policy implications of the research. The limitations and avenues for future research are discussed before the concluding remarks.

\section{Literature Review, Conceptual Model, and Hypothesized Relationships \\ 2.1. Theory and Concepts}

$\mathrm{AI}$ as a specific case of EI is a person's readiness, willingness, or commitment to pursue a self-employed agribusiness career $[9,26,36,44]$. AI is based on the opportunity recognition that directs and guides the actions of an individual toward the development and implementation of the agribusiness concept $[38,45]$. It might be viewed as the first step in an evolving, long-term agripreneurship process [18]. In most EI research, it appears that the TPB has been used extensively to explain the intention to start a business $[19,23,28,38,46]$. The wide reliance on the TPB could be explained by its inclusiveness and comprehensiveness [18]. Based on the TPB, we assume that agripreneurial behavior is planned, reasoned, and controlled in anticipation of the likely consequences [18]. Therefore, the higher the intention to engage in agribusiness, the more likely it is that effective agribusiness engagement will occur [19,23]. The TPB proposes that EI is driven by three factors [38]: a positive evaluation of the behavior (attitude), the perception of the easiness of performing the behavior (perceived behavioral control or feasibility), and the perceived social pressure to perform the behavior (social or subjective norms). Empirical evidence supports the TPB by showing that intention predicts the behavior to a large extent $[9,29,46]$. The reliability of the TPB has been confirmed in several studies, and its constructs have been found to predict more than $50 \%$ of the variance in EI [23,31,47]. However, there is a variance in the predictive power of the TPB across EI studies and contexts [23,48]. This study will thus test the TPB in the context of agribusiness, which has so far been ignored. Based on the TPB, this research argues that youths' AI is driven by their PC, which could also depend on their perception of agribusiness-related social norms [15].

The PC is a positive state of mind formed of four constructs that best define and meet the inclusion criteria of positive psychology [38]. These constructs include selfefficacy, optimism, hope, and resilience $[38,49,50]$. Self-efficacy refers to beliefs in one's competencies or the degree to which a person feels able to mobilize the resources and courses of action needed to successfully perform a specific task [14]. In this study, the focus is placed upon agripreneurial self-efficacy, rather than general self-efficacy. Hope captures an individual's ability to set goals, and their perceived capabilities to devise achievable paths to attain their desired goals $[25,38,51-53]$. Optimism is a generalized expectancy that one will experience a good outcome for undertaking one's chosen activity $[25,38]$. This would apply to one's like or dislike for a given career or task [54]. Resilience is the extent to which someone can bounce back from negative experiences or failures and adapt to changing and stressful life events [38,55]. Resilience is often enabled by creativity, flexibility, and adaptability [56].

The TPB does not implicitly refer to PC as an antecedent of EI; however, we argue that the TPB constructs of attitude and perceived behavioral control overlap with the PC dimensions of optimism and self-efficacy, respectively [38,51]. Thus, what we add to the TPB is the PC dimensions of resilience and hope.

The PSN dimensions include normative beliefs and the social valuation of agribusiness career [40,47]; however, it was only recently that research included the social valuation of an entrepreneurial career among the constructs of PSN [38]. We hope that the construct of the social valuation of an agribusiness career makes sense in the DRC context under examination. In this context, it looks like youths are often reluctant to engage in agribusiness because agriculture is associated with lower class and rural people in society [57,58]. It follows, therefore, that low agripreneurial intention could also be exacerbated by the lack of role models who have succeeded in agribusiness [59]. Arguably, the low social value associated with agribusiness activities also means that the sector does not attract positive social support within the youths' social networks [60,61]. This view is also supported by the 
rate of youth rural-to-urban migration, even when majority of these youth migrants do not qualify for any urban employment $[4,62]$. This paper argues that there is a vicious cycle of negative social norms associated with the agricultural sector and low psychological capital among the youth, which potentially prohibits youths from engaging in agripreneurship. Youths would not feel confident enough to engage in agribusiness activities when the sector is left to illiterate people for survival reasons only.

Despite the success of the TPB in behavioral research, the EI research has been criticized by some scholars, who argued that intention does not necessarily translate into actual business start-up behavior $[63,64]$. The argument has been supported by the emergence of the enactment theories, such as effectuation, bricolage, and improvisation [64-67]. The criticisms, however, neither nullify the TPB nor the relevance of EI research. Instead, they urge scholars to be careful in concluding about the occurrence of actual behavior based on intention.

Building on the Theory of Reasoned Action [31,68], this study adopts the TPB to posit that favorable perception of agribusiness-related social norms, and $\mathrm{PC}$ have a positive and significant effect on AI among youths in the Eastern DRC. In the next lines, we explain the causation mechanisms and justify the formulated hypotheses.

\subsection{PSN-AI Relationship}

PSN refers to the belief of someone on how well or bad his/her decision will be judged or valued by the people and organizations around him/her from whom he/she expects the necessary support to carry out the behavior $[13,22]$. Thus, within the content of this research, PSN includes two dimensions: normative beliefs and social valuation [38]. The normative beliefs regulate how individuals perceive their peers and other close and important people's views on whether they should engage in agribusiness [69]. Consequently, a positive perception of the social norms toward agripreneurship would increase the youth's confidence and belief that they would receive support for their would-be agribusiness ventures [40]. The perceived support would take various forms, such as business start-up financial capital, moral or emotional encouragement, business ideas, land, tax reduction or exemption, capacity building, and the marketing of products, to name a few. Therefore, PSN translates to the social valuation by the youth of how entrepreneurs in the agricultural value chain are socially perceived, and whether they are supported and enjoy high respect in the society [70]. Under these circumstances, the desirability of agribusiness as a career choice among youths will increase with the perception that such activities are socially valued, and that those already involved in agribusinesses are supported within their networks [71]. [45]. The social valuation of agribusiness reflects the stereotypical perception of the 'successful agribusiness owner' in society [2,23], which serves to legitimize agribusiness activities [13]. Some scholars have argued that the lack of local role models and champions who have succeeded in agriculture $[4,6]$ and the negative stigma associated with those involved in agricultural activities [72] would discourage youths from aspiring to pursue a career in agriculture. Within the meaning of this research, "favorable perception of social norms about agribusiness" is the perception by the individual that agribusiness is a socially valued, supported, and respected career.

With this in mind, it can be hypothesized that:

Hypothesis 1 (H1). The favorable perception of social norms about agribusiness as a career option has a positive effect on youths' intentions to engage in agripreneurship in the Eastern DRC.

\subsection{PC-AI Relationship}

The positive effect of PC (self-efficacy, optimism, hope, and resilience) on EI has been found in a few studies that have been conducted on this subject [25,38]. We draw upon this to argue that the relationship between PC and AI would be positive. Youths who have a higher agripreneurial self-efficacy would believe in their abilities to succeed in performing agribusiness activities; thus, they would be committed to engaging in agribusiness [42]. 
Similarly, optimistic youths can recognize agribusiness opportunities where others see chaos, contradiction, or confusion [53]. Hope could help the youths to capitalize on those opportunities by setting realistic and achievable goals [52]. Resilient youths could be able to tolerate agribusiness risks and uncertainties because whatever happens, they can bounce back from failures and adversity [25]. With this in mind, it is hypothesized that:

Hypothesis 2 (H2). PC has a positive effect on youth AI in the Eastern DRC.

\subsection{Mediating Role of PC in the PSN-AI Relationship}

Several studies suggest that PSN does exert its influence on EI, but only through the mediating role of psychological factors $[18,19,31,63]$. To this end, an empirical study found no relationship between PSN and EI, but the results found a strong positive relationship between PSN and optimism [31]. Research has found that PSN drives EI through its effect on personal attraction (optimism) and self-efficacy levels [19,63]. Similarly, perceived social support was found to significantly shape the EI of young people through cognitive factors [18]. Support for the argument that people's self-efficacy can be strengthened by the influence from respected significant others who may endorse them and provide positive feedback on the progress being made on a particular task is documented in the existing literature [55].

Thus, the research seems to agree on the role of self-efficacy and optimism in mediating the relationship between PSN and EI. However, there is still a gap in the literature regarding the mediating role of PC comprising self-efficacy, hope, optimism, and resilience. This study assumes that PSN indirectly influences AI through its influence on PC. We argued that when the social beliefs and values towards agribusiness are favorable, the youth would perceive that his/her decision to become an agripreneur will be socially valued and supported; this potentially enhances his/her PC to pursue the agripreneurial career. This paper aligns with the view that research on EI should shift from traditional models, which assume explanatory variables to directly and independently explain intention, to an approach that accounts for indirect influences [15]. Therefore, it is hypothesized that:

Hypothesis 3 (H3). PC positively mediates the effect of PSN on AI among youths in the Eastern DRC.

\subsection{Moderators of the PSN-AI Relationship}

The research considers some variables that have the potential to moderate the relationship between PSN and AI. These variables include gender, location, educational level, access to funds, and land. Support for the direct effect of these variables on the EI has often been found in exiting studies $[27,45,73,74]$, but little research has examined their moderating effect on the relationship between PSN and EI. We contribute to addressing this knowledge gap based on AI, with the objective of clarifying the conditions under which PSN could drive EI.

Gender has often been found to be a factor in career preferences [45,73]. In the context of Sub-Saharan Africa, the female percentage of participation in the agricultural value chain is higher than that of men [75]. Similarly, women are disproportionately under-represented in most formal sectors of the economy, except in agriculture, which coincidentally remains predominantly subsistence-based and underdeveloped. By extension, women's work is often associated with the agricultural sector, and this is reflected in the social values and beliefs. Thus, we posit that:

Hypothesis $4 \mathbf{a} \mathbf{( H 4 a )}$. The effect of PSN on AI is stronger among females than males.

Other studies $[76,77]$ have indicated that youth living in or originating from rural areas are more likely to engage in agribusiness compared to their urban counterparts. This could probably be explained by the fact that rural youth are more used to farming, 
and have limited opportunities (in terms of education and social networks) to access the labor market in urban areas [78]. Therefore, favorable PSN could lead to a more positive inclination towards agribusiness among rural youths than it could do among urban youths. Hence, we tested the following hypothesis:

Hypothesis $4 \mathbf{b} \mathbf{( H 4 b )}$. The effect of PSN on AI is stronger among rural youths compared to urban youths.

The probability to engage in agricultural activities decreases with the educational level [75]. The higher the educational level, the higher the probability that the youth would prefer salaried employment $[57,79-81]$. Youth often strive toward the pursuit of higher degrees at universities that are situated away from their villages, and after graduation, they do not prefer to return to their homes and/or to participate in agriculture [2]. With this in mind, we expect higher education to be a decelerator of the effect of PSN on AI. Hence, we hypothesize that:

Hypothesis 4c (H4c). The effect of PSN on AI is stronger for less-educated youths compared to the most educated.

Youths' access to financial resources is cited among the successful factors to engage them in agribusinesses [57,59]. Youth do not have access to funds, or at best they only have limited funding opportunities, something which may explain their lower interest in engaging in agribusiness. Like any entrepreneurial activity, funds are important to acquire any other type of resources to launch and sustain the agribusiness venture. However good or positive the perception of the youths regarding agribusiness' social norms, their interest to pursue the agripreneurial career might remain low unless they perceive that they can get the necessary funds to implement their ideas. It can therefore be hypothesized that:

Hypothesis $4 \mathbf{d}(\mathbf{H} 4 \mathbf{d})$. The effect of PSN on AI is stronger amongst youths who have access to funds than others.

Access to land is also cited among the factors influencing youths' intentions to engage in agribusiness. Access to land is a prerequisite for most types of agribusinesses [59]. Land ownership is needed for farming, besides being the most common form of security that financiers accept as security against agricultural loans [82]. Youth, even those interested in farming, are largely excluded from land ownership in Sub-Saharan Africa, where gerontocracy and agrarian inequality still prevail, and further discourage youths when they consider a career in agribusiness $[59,82]$. Therefore, it may not be enough to hold a perception that agribusiness is a socially valued and respected career that attracts public support. In addition to this, land ownership is important. We can thus posit that:

Hypothesis $4 \mathbf{e} \mathbf{( H 4 e )}$. The effect of PSN on AI is stronger among youths who can easily own land.

Taken together, the formulated hypotheses can be presented in the following conceptual model in Figure 1. 


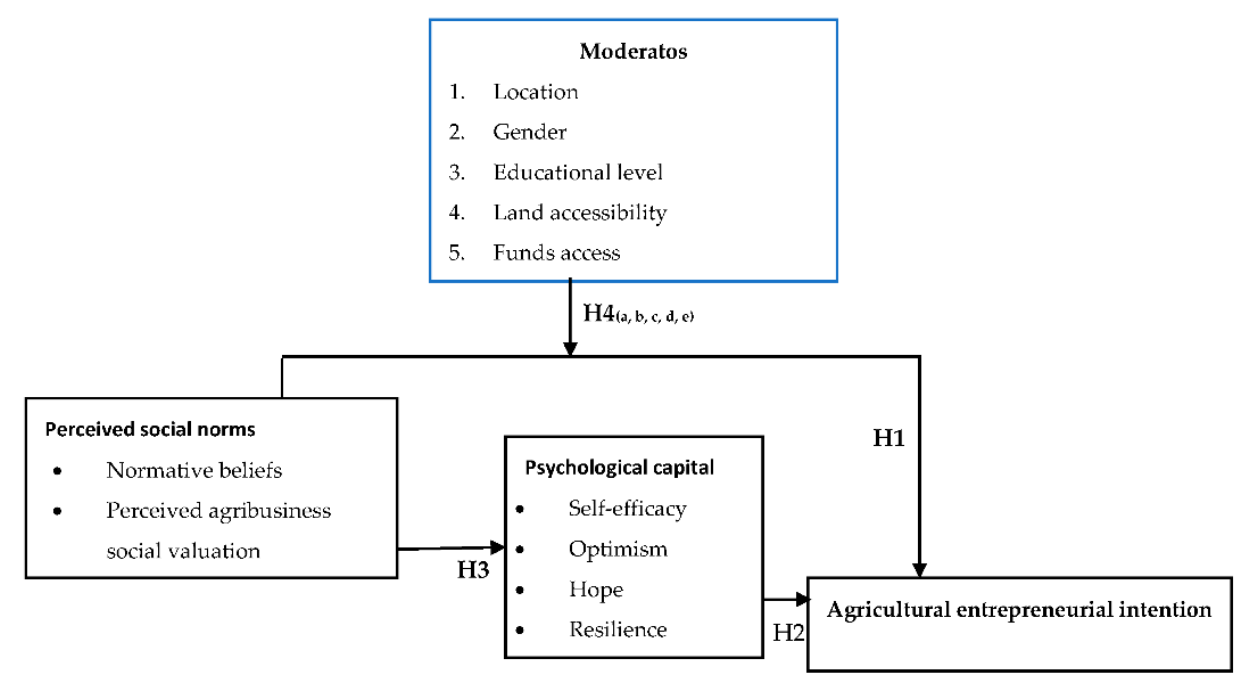

Figure 1. Conceptual model.

\section{Materials and Methods}

The population for this study was Congolese youth aged between 18 and 35 years, based on the African Union Youth Charter age bracket of youth definition [83]. We focused on youths because they are the most affected by unemployment [84], but they have the potential to contribute to the prosperity of the country if properly exploited. The sample was drawn from the South Kivu Province in the Eastern Democratic Republic of the Congo. The primary data was collected from a randomly selected sample of 600 youths within the corridor of Bukavu, Uvira, Fizi, and Kelehe, where there are world Bank interventions. The qualifying participants were those youths who had not yet started any business in the agricultural value chain. The data was collected through a manual questionnaire in a cross-sectional research design [84,85]. We used 10 enumerators, who first benefited from data collection training to prevent some challenges. The respondents were found at their respective homes, and the survey was conducted at the hours most convenient to the respondents.

The measurement instrument and the multi-item scales applied were largely adapted from previous studies. Multi-item scales were preferred for their advantage of allowing the measurement errors to be canceled out against each other, thus improving the reliability and validity of the scales [41]. A 5-point Likert scale was used to capture the respondents opinions and perceptions about the different statements [86].

AI was measured through the 12 items $[40,87]$ listed in Appendix A. Besides this, we classified the youths' professional alternatives and asked the respondents to select them by order of preference [77]. The PSN instrument was adapted from the existing literature $[18,34,40,44]$. Its measurement included 15 items subdivided into two dimensions: normative beliefs (NB) and the perceived social valuation (PSV) of agribusiness, as per Appendix B. The PC research instrument was adapted from a study [25] that links PC to EI in the context of youths. The PC dimensions of hope, self-efficacy, optimism, and resilience were measured with a total number of 24 items that met the inclusion criteria of being positive, unique, and theoretically valid, and research-based, measurable, changeable, and manageable for performance improvement $[55,88,89]$. These items are listed in Appendix C.

The research instruments used were slightly modified to fit the agricultural and the Eastern DRC contexts. To this end, the reliability and validity of the measurements were tested.

Gender was captured as a binary variable ( 1 for male and 0 for female). Education level was coded 0 for sub-diploma level, 1 for diploma level, 2 for undergraduate level, 3 for bachelor level, and 4 for master's degree and above. The location data was collected between rural areas (coded 1) or urban settings (coded 0). Access to arable land and 
financial capital were captured using a 5-point Likert scale (ranging from 5: most accessible to 1: least accessible).

The mean indexes of the variable items were analyzed to examine the extent to which youths are willing to pursue agribusinesses, how they evaluate their PC, and whether they think their peers, organizations, and people important to them would support and value their decision to engage in agribusinesses [23,38]. Structural Equation Modeling (SEM) was used to test the research hypotheses, besides also serving for confirmatory factor analysis. To reduce the structural model's complexity, the items related to each dimension were averaged to obtain an index [41]. Thus, the parameters of the following model were estimated:

$$
\begin{gathered}
\mathrm{AI}=\mathrm{i}_{1}+\mathrm{c}_{1} \mathrm{PSN}+\mathrm{e}_{1} \\
\mathrm{AI}=\mathrm{i}_{2}+\mathrm{c}_{2} \mathrm{PSN}+\mathrm{mPC}+\mathrm{e}_{2} \\
\mathrm{PC}=\mathrm{i}_{3}+\mathrm{aPSN}+\mathrm{e}_{3} \\
\mathrm{AI}=\beta_{0+} \beta_{1} \mathrm{PSN}+\beta_{2} \mathrm{PC}+\beta_{3} \mathrm{LOCATION}+\beta_{4} \text { GENDER }+\beta_{5} \text { EDUCATION }+ \\
\mathrm{v}_{6} \mathrm{LAND}+\beta_{7} \text { FUNDS }+\beta_{8} \text { PSN }^{*} \mathrm{LOCATION}+\beta_{9} \text { PSNxGENDER }+ \\
\beta_{10} \text { PSN } x \text { EDUCATION }+\beta_{11} \text { PSNxLAND }+\beta_{12} \text { PSNxFUNDS }+\mathrm{e}_{4}
\end{gathered}
$$

The Partial Least Squares (PLS) method was used to estimate the parameters of the SEM [60,89-91] with the help of PLS Smart software [92,93]. The advantages of PLS-SEM in this context were that it enabled us to examine the relationships among the simultaneously separate but interdependent equations of the model $[86,94,95]$, and that it provides information on how well the conceptual model fits the data [96]. It minimizes the measurement errors in the endogenous latent variables [92,97]. In addition, PLS-SEM reduces the bias in the estimators [48], regardless of the normality of the variables, and is suitable even if the sample size is small $[47,95,97]$. PLS-SEM was used because we were concerned with testing a theoretical framework from a prediction perspective, and we used variable scores for the follow-up analyses [97]. The method is also credited with a high degree of statistical power, implying that PLS-SEM is more likely to identify relationships as significant when they can indeed be found in the population [92,97]. The PLS-SEM was appropriate because we tested for moderation and mediation effects [95].

The coefficient ' $\mathrm{C}_{2}$ ' in equation 2 defines the effect of the independent variable-PSNon the outcome variable, controlling for the mediating variable, and represents the direct effect. The coefficient ' $m$ ' defines the effect of the mediating variable on the outcome, controlling for the independent variable. The coefficient ' $a$ ' in equation (3) defines the effect of the independent variable on the mediating variable. The ' $\mathrm{c}_{1}$ ' coefficient represents the overall effect of the independent variable on the outcome variable, also known as the total effect. The product of the ' $a$ ' and ' $m$ ' coefficients defines the indirect effect of PSN on AI through PC.

Equation (4) indicates that the research examines the moderating role of youth location $\left(\beta_{8}\right)$, gender $\left(\beta_{9}\right)$, level of education $\left(\beta_{10}\right)$, land accessibility $\left(\beta_{11}\right)$, and funds $\left(\beta_{12}\right)$ on the relationship between PSN and AI, controlling for the effect of PC $\left(\beta_{2}\right)$. The two-way moderating effect is confirmed if the estimates of the independent variable, the moderating variable, and the interactions between the independent and moderating variable are significant concurrently [98].

\section{Results}

\subsection{Sample Characteristics and Descriptive Statistics of the Study Variables}

As indicated in Table 1, 72.5\% of the respondents were male, and were 23 years old on average. The respondents reported a higher chance (63\%) of getting access to arable land for any agribusiness-related venture, implying that land is not a barrier to agripreneurship. Only $39 \%$ of the respondents were positive about the probability of accessing financial capital and resources. About $60 \%$ of the youths were not confident in their ability to raise or access the necessary agribusiness start-up funds. 
Table 1. Average values of variables used.

\begin{tabular}{|c|c|c|c|c|}
\hline Variable/Dimension & Mean & $\%$ & z-Stat & Prob. \\
\hline $\mathrm{AI}$ & 3.413 & 60.3 & 10.3 & 0.00 \\
\hline Normative beliefs & 3.195 & 54.9 & & \\
\hline Perceived social valuation of agribusiness & 3.432 & 60.8 & & \\
\hline PSN & 3.314 & 57.8 & 7.6 & 0.00 \\
\hline Self-efficacy & 3.615 & 65.3 & & \\
\hline Hope & 3.693 & 67.3 & & \\
\hline Optimism & 3.527 & 63.1 & & \\
\hline Resilience & 3.476 & 61.9 & & \\
\hline PC & 3.578 & 64.4 & 14.2 & 0.00 \\
\hline Age (in years) & 22.97 & & & \\
\hline Land access & 3.52 & 63 & & \\
\hline Fund access & 2.77 & 39 & & \\
\hline The proportion of rural youths & & 56 & & \\
\hline Proportion of males & & 72.5 & & \\
\hline
\end{tabular}

The $p$-value (z-statistic) tests whether the mean scores of the three focus variables are equal to or higher than 2 (neither agree nor disagree), as shown in Table 1.

The majority (60.3\%) of the respondents exhibited significant positive intentions (significantly higher than $50 \%$ ) to pursue agribusiness activities. The majority of the respondents were positive that they are likely to be supported by their families, friends, colleagues, the government, and financial and other institutions in the pursuit of agribusiness activities. Although the PSN average score is significantly higher than 3, the finding implies that about $45 \%$ of the youth believe that their social networks are not ready to support their agribusiness ventures. Agricultural and other related agribusiness activities are perceived to be less socially desired by about $39 \%$ of youths. This category of respondents believes that agripreneurs do not enjoy much respect in society and are less resourceful and considered incompetent. Furthermore, the respondents reported a psychological capital level of $64.4 \%$, with hope and self-efficacy contributing more than the resilience and optimism dimensions.

The most preferred professional career by the youth is to work as employees in NonGovernmental Organizations (NGOs), for which higher salaries and social prestige are expected (Table 2). The preference for self-agribusiness employment comes at the fourth position, while the least preferred career choice is to work as an agribusiness employee.

Table 2. Agribusiness desirability compared to other professional career options.

\begin{tabular}{cccc}
\hline Code & Professional Career Choice & Mean & $\%$ \\
\hline A & Agripreneur & 3.734797 & 68.37 \\
B & Agribusiness employee & 2.442568 & 36.06 \\
C & Private sector business owner & 3.780405 & 69.51 \\
D & Private sector employee & 2.967905 & 49.20 \\
E & Public sector servant & 3.739865 & 68.50 \\
F & NGO employee & 4.081081 & 77.03 \\
G & University employee & 3.532095 & 63.30 \\
\hline
\end{tabular}

\subsection{Regression Analysis-SEM Empirical Model}

The empirical model is presented in Figure 2, and the important findings for the moderation and mediation analysis are summarized in Table 3. 


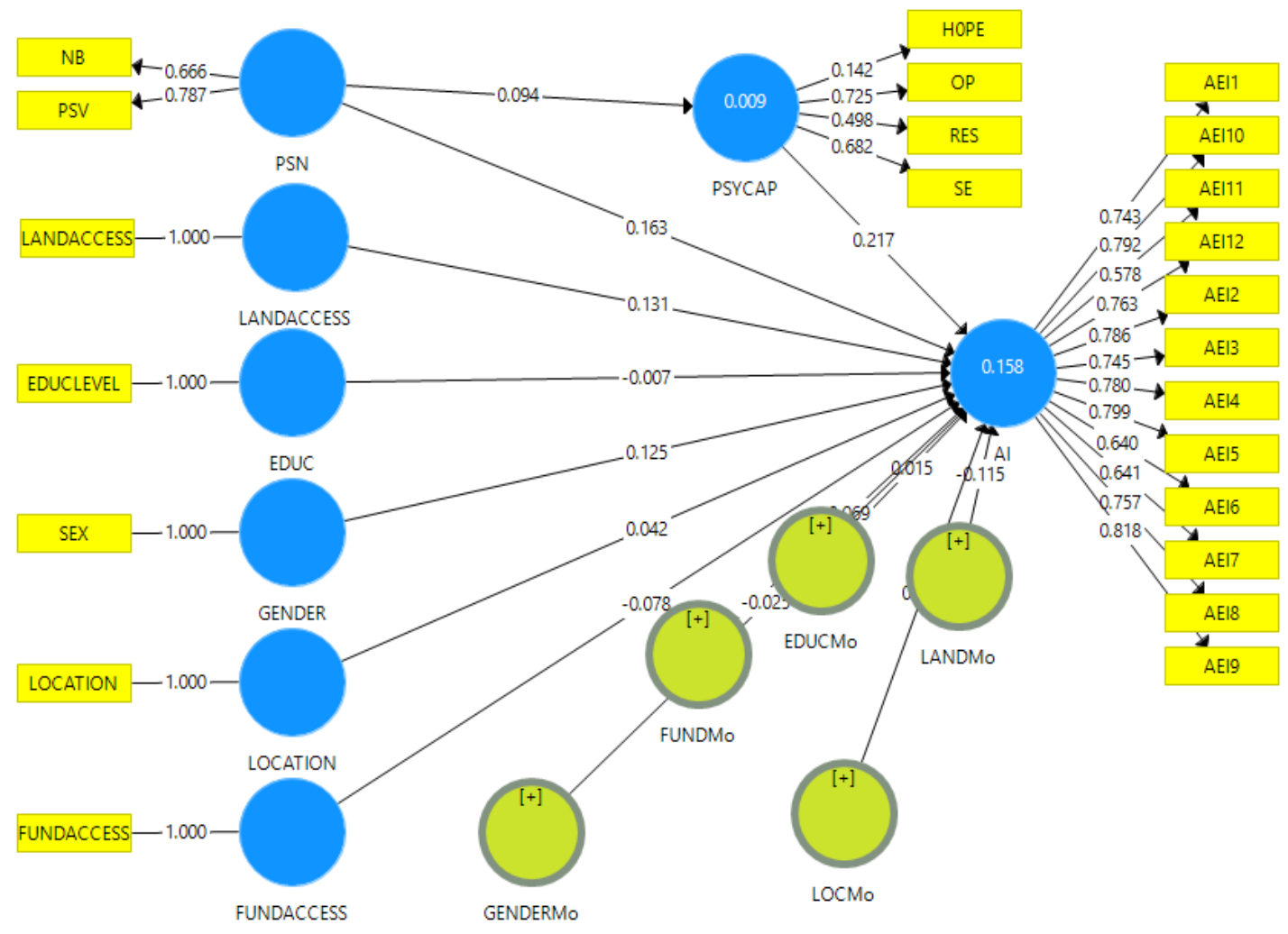

Figure 2. Empirical model.

Table 3. SEM-PLS results.

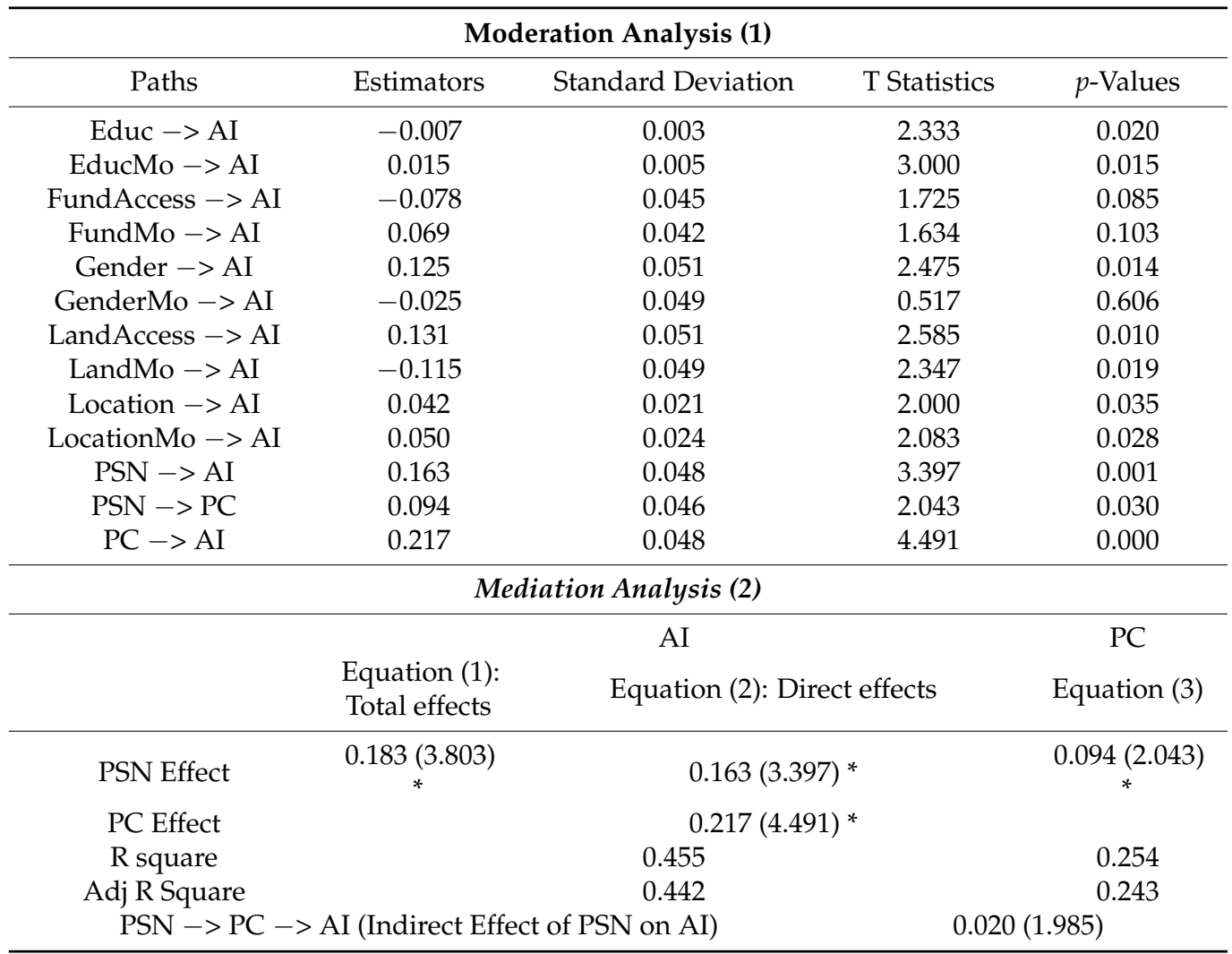

${ }^{*}$ Effect is significant at $5 \%$. 
PC postively and significantly drives the intention to engage in agribusiness, which supports hypothesis $\mathrm{H} 2$. An increase of PC by $25 \%$ corresponds to an increase of the intention to engage in agribusinesses by $5.425 \%$. The hypothesis $\mathrm{H} 1$ is empirically supported because PSN positively and significantly influences AI among the youth, but to a lower extent compared to PC. When youth perceive that agribusiness is socially desired and that they can be supported, they feel confident enough to embark on an agripreneurial career. The intention to engage in agribusiness increases by $4.1 \%$ when the perception of social norms improves by $25 \%$.

Rural youth are most interested in agribusiness and other related agricultural activities compared to those living in the urban zones, and the difference of intention levels among the two groups is significant. Educational level negatively and significantly influences the intention to become an agripreneur.

The positive effect of PSN on agripreneurial intention is much stronger (or accelerated by $1.25 \%$ ) when youth live in a rural area. Thus, the findings fully support $\mathrm{H} 4_{\mathrm{b}}$, because the moderation effect of youth location is significant. Educational level positively (and significantly) moderates the relationship between PSN and the intention to engage in agribusiness activities, unlike what was expected in $\mathrm{H} 4_{c}$. This means that the favorable perception of the social norms regarding agribusiness activities leads to a significant increase in the intention to engage in agribusiness, but the effect is much stronger among youths with higher degrees.

Females exhibited a slightly higher intention to engage in agribusiness $(3.125 \%)$ than males, the gender difference is significant. Although the moderating effect of gender is significant, the sign associated with the gender moderation means that the effect of PSN on $\mathrm{AI}$ is weaker among women compared to men, unlike what was expected in $\mathrm{H} 4_{\mathrm{a}}$.

Access to land positively and significantly drives agribusiness intention (Table 3). This may be explained by the fact that most youths associate agribusiness activities with farming, and this requires having land as a starting point. Unlike what was expected in $\mathrm{H}_{e}$, the effect of PSN on AI is weaker among youths who have farming land. The perceived access to financial resources negatively and significantly (at a 10\% margin error level) drives the intention to engage in agribusiness activities. The intention of youths to engage in agribusiness decreases by $1.95 \%$ if the probability that they can access funds increases by $25 \%$. Therefore, giving out money to youths is not enough for their effective engagement in agribusiness activities, all other things being equal. Support for $\mathrm{H} 4_{\mathrm{d}}$ was not found, because unlike what was expected, access to funds positively but not significantly moderates the effect of PSN on AI.

Using the causal steps procedure [91], the mediation role of PC is supported (H3) because PSN is significant ( $p$-value $<0.05, z$-value $>1.96$ ) in regressions (1) and (3); PC is significant in regression (2), and the effect of PSN on AI ( $c_{2}=0.163$ and $\left.z=3.397\right)$ is less in equation two compared to equation one ( $c_{1}=0.183$ and $\left.z=3.803\right)$.

However, the effect of PSN on AI is partially mediated by PC, because PSN has a direct and significant effect on AI (Equation (2)).

In absolute terms, the total effect of PSN on $\mathrm{AI}$ is equal to 0.183 . This includes a direct effect of 0.163 and an indirect effect of $0.02\left(0.094^{*} 0.217=0.02\right)$. The direct effect of PSN is equal to $4.075 \%$, and its effect-which is channeled through PC-is equal to $0.5 \%$. However, the direct effect of PC is higher (0.217) than the total effect of PSN (0.183) on AI, which is something that makes the former an important target of policymakers. The structural model predicted $24.3 \%$ of the variance in PC and $44.2 \%$ of the variance in AI.

The three constructs of AI, PSN, and PC exhibited large Cronbach's $\alpha$ coefficients of $0.91,0.80$, and 0.86 respectively (Table 4 ), all of which are higher than the recommended threshold of 0.7 [87]. The instrument's measurements exhibited internal consistency, and were therefore reliable. The average variance extracted (AVE) was higher or equal to the threshold of 0.5 [94,97]. The joint information from the variables' reliability and the AVE values show that all of the measures exhibit convergent validity. The discriminant validity was examined by resorting to the correlation matrix between the three latent 
variables $[38,97]$. All of the values of the squared coefficient of correlation between the variables are below the attached average variance extracted. The results confirm that each construct is distinct from the others, implying that discriminant validity is satisfied [86,95].

Table 4. Reliability, validity, and fitness analysis.

\begin{tabular}{|c|c|c|c|c|c|c|}
\hline Variables & AI & PSN & PC & KMO & $\begin{array}{c}\text { Extracted } \\
\text { Variance (AVE) }\end{array}$ & $\begin{array}{c}\text { Cronbach } \\
\alpha\end{array}$ \\
\hline $\mathrm{AI}$ & 1 & & & 0.944 & 0.5372 & 0.9194 \\
\hline PSN & $0.496(0.246)^{* *}$ & 1 & & 0.847 & 0.5018 & 0.8022 \\
\hline PC & $0.597(0.356)^{* *}$ & $0.429(0.184)^{* *}$ & 1 & 0.892 & 0.5551 & 0.866 \\
\hline \multicolumn{2}{|c|}{ Fitness indicators } & Saturated Model (1) & \multicolumn{2}{|c|}{ Estimated Model (2) } & \multicolumn{2}{|c|}{ Acceptable limits for (2) } \\
\hline \multicolumn{2}{|c|}{ Standardized Root Mean Square (SRMR) } & 0.058 & \multicolumn{2}{|c|}{0.059} & \multicolumn{2}{|c|}{$<0.08$} \\
\hline \multicolumn{2}{|c|}{ d_ULS } & 0.944 & \multicolumn{2}{|c|}{0.945} & & \\
\hline \multicolumn{2}{|c|}{ d_G } & 0.288 & \multicolumn{2}{|c|}{0.293} & & \\
\hline \multicolumn{2}{|c|}{ Chi-Square } & 711.331 & \multicolumn{2}{|c|}{712.188} & & \\
\hline \multicolumn{2}{|c|}{ Chi-Square/Degree of freedom } & & \multicolumn{2}{|c|}{1.707} & \multicolumn{2}{|c|}{$<5$} \\
\hline \multicolumn{2}{|c|}{ Normed Fit Index (NFI) } & 0.783 & \multicolumn{2}{|c|}{0.783} & \multicolumn{2}{|c|}{0 (worse) to 1 (perfect fit) } \\
\hline
\end{tabular}

Notes: ( ), squared coefficient of correlation between variables. ${ }^{* *} p \leq 0.01$.

The conceptual model's fitness to the data was good enough, as the SEM empirical model was closer to the saturated model. This implies that the distance between the model and data was shorter [92]. Besides this, the values for the SRMR (Standardized Root Mean Square Residual), chi-square, and NFI were found to be within the acceptable limits $[38,92]$.

\section{Discussion}

This research started from the argument that the weak participation of youths in the agricultural value chain in the DRC negatively affects food security and undermines the government's efforts to drive economic growth and reduce unemployment. The study applied the theory of planned behavior to argue that attempts to involve youths in the agribusiness sector should begin by examining the youths' intentions to pursue opportunities in the agricultural sector. This paper further examined whether policymakers could act upon social norms and youths' PC to increase youths' intentions to engage in agribusinesses. The research questions were based on re-examining the effect of subjective norms (herein operationalized as perceived social norms) on entrepreneurial intention. So far, the literature has not found conclusive evidence that supports this hypothesized effect $[13,47]$. This study made a significant contribution to the existing literature by showing that the direct relationship between perceived social norms and entrepreneurial intention is incomplete unless we account for the mediating role of PC and the moderating roles of other variables such as gender, educational level, location (rural vs. urban), and access to land.

Although the youths reported an agripreneurial intention level of $60.3 \%$, the findings indicated that employment in NGOs is their most preferred career choice. This is not surprising in the context of the DRC, where social services are largely supported by international organizations that tend to be more visible, active, and seemingly stable providers of employment. The intention level to pursue agribusiness activities is inconsistent with the anecdotal evidence that suggests that the number of youths who effectively engage in agribusinesses is low in comparison to other sectors. This inconsistency does highlight a significant gap between intention and actual behavior, as has often been reported in previous studies $[15,24,41,67]$.

The results show that the variance in the intention to engage in agribusiness activities among the DRC youth is better explained by PC than PSN. While the socio-cultural context is important in policymaking, this study shows that the focus should be more on changing youths' mindsets. Importantly, existing studies have reported that PC is a state which can be built, developed, and managed $[30,55]$. It can therefore be argued that it is possible to 
promote agribusiness among youths by improving their self-efficacy, optimism, hope, and resilience. The finding's implication is particularly salient at a time the dialogue among researchers and policymakers is about youth employability and the soft skills required in the fourth industrial revolution $[99,100]$. Hence, we consider PC to be one of those skills.

The results also indicated that the youths that perceive agribusiness to be a socially desired, valued, and supported career also exhibited higher PC and intention to engage in agribusiness. The significance of PSN as a driver of the intention to engage in agribusiness is consistent with previous research that concluded that many Congolese from South Kivu expect their children to earn an academic qualification to be most qualified for formal employment [38]. This also has to do with the cultural tendency among graduates to be 'job seekers', despite the scarcity of jobs [9]. Therefore, as reported by [78], some youths do not consider pursuing an agripreneurship career because they associate it with farming, which is far from the seemingly dynamic lifestyles offered by cities.

The effect of PSN on the AI was much stronger among males, the most educated, rural youths, and those who would not have access to land. Moreover, support for the positive mediation role of psychological capital was found. The significance of the moderator, and the independent and mediator variables, strengthens the view that youths should not be treated as homogeneous groups with similar perceptions, interests, capabilities, and sociocultural backgrounds [6,57]. These findings have practical, theoretical, and methodological implications.

\subsection{Practical Implications}

While further research is needed in the study's context, a first step to increase the rate of youth agribusiness ownership and participation might be to focus on their PC and the perceptions they have about the social beliefs and values associated with agribusiness activities. In this regard, policy actions targeting youths with higher PC, and who perceive agribusiness to be a socially desired and supported endeavor, are likely to succeed. Those that transition from intention to actual business creation in the agricultural sector will in turn provide the local youths with role models on agripreneurial success.

We do acknowledge that there is a long way to go about changing youths' values and beliefs about agribusiness as a career option because social norms are culturally embedded [16]. However, deliberate steps to highlight agribusiness success stories in news media would have a positive impact on youths' inclinations towards agribusiness. Equally, interaction between youths and successful agripreneurs might have a positive effect in changing the way youths perceive agripreneurship as a career option. Formal approaches to agripreneurship education may be complemented by tacit learning with peers [101]. This will induce positive emotions and build the participants' PC to pursue an agripreneurial career. There is a need to design awareness programs that educate people on the important role that agripreneurs play in driving prosperity. This will serve to increase the social acceptance of agribusiness as a career option. Such programs would also raise the societal awareness of the important economic role youths can play through engaging in the agricultural value chain, and would mark a departure from the traditional ideologies that perceive youths as job seekers.

This study recommends that skill-building in the dimensions of PC-self-efficacy, hope, optimism, and resilience-might be a significant addition to the content of agribusiness education. Lecturers should aim at offering a feasible preview of agribusiness ownership that vaccinates against negative expectations and enhance PC among the learners. This will induce a positive change in the perception of agribusiness as a career option, and will increase the propensity to act upon agribusiness opportunities. Similarly, the use of local case studies in the training of agribusiness would be instructive about enhancing youths PC, which enables their intention and later their actions. Successful young agripreneurs could be invited to deliver agripreneurship lectures, or to share their experience with the learners. This could increase learners' confidence and optimism in choosing an agribusiness career. Because PC is affected by external factors [38,52,102], it would be good for 
the government to continue to enable the agribusiness environment so that youths feel confident to engage in successful agripreneurship.

The majority of the youths surveyed did not find access to financial resources to be a significant impediment to agripreneurship. Ironically, the intention to engage in agribusiness decreased with the perception that the youth would have access to financial resources. Thus, youths would prefer to invest any amount of money raised in other sectors than in agribusiness. Therefore, policymakers should not prioritize actions enabling youths to access financial resources unless they are designed for the youths who are already interested in venturing into agribusiness. We found out that the relationship between the favorable perception of social norms and AI was positively and significantly moderated by the youth's educational level and rural location. The meaning of the moderating effects of education and location is that the most educated youth and those living in rural areas feel more confident to engage in agribusiness activities when they perceive that their choice will not be socially rejected or underestimated.

Therefore, we call upon different policy actions. In this regard, the starting point to involve youth with university education and rural youths in agribusiness is to increase their agribusiness awareness and interest, whereas for the less educated and urban youths the focus might be placed on helping them to concretize their agribusiness desires.

The finding of the moderating role of gender implies that acting on social norms to engage youths in agribusiness is most likely to be effective for males compared to females. The effect of PSN on AI was weaker among the youths who have farming land. This could mean that the positive perception of agribusiness came with land possession, rather than what the youth think is the social belief about the agribusiness value.

\subsection{Theoretical and Methodological Implications}

While the findings support the generalizability of the TPB across contexts, they contribute to the existing literature by documenting the specific case of agribusiness, and by showing that PC serves as the missing link in the often-reported weak relationship between PSN and EI $[13,46]$. The research implies that, beyond perceived the behavioral control and attitude implicitly used in the TPB as either the independent variable or intermediate step between subjective norms and EI [47,103], there is a need to include a broader set of psychological variables, such as the PC construct operationalized in this study. The research also makes a theoretical contribution by showing that unless we account for the conditions under which PSN drive the intention to engage in agribusiness, the relationship between the two variables would remain incomplete or miscomprehended at best. Thus, this research confirms the moderating roles of educational level, gender, location, and access to land. Therefore, we argue that the individual demography-related variables should complement the TPB constructs if EI is to be sufficiently explained. For a better understanding of the social embeddedness of intention, PSN dimensions need to be extended beyond normative beliefs and normative belief compliance to include a specific focus on the perceived social valuation of a specific entrepreneurial career. Finally, the research shows that it is worth aggregating PSN dimensions rather than using them individually, if the entrepreneurial context is to be comprehended holistically.

\section{Conclusions, Limitations, and Opportunities for Future Research}

Intentions are widely known to be a vital antecedent of actual behavior [24,38]; however, support for the link between perceived social norms (subjective norms) and entrepreneurial intention has not often been found in the literature. This is something that seems to underestimate the influence of social values and beliefs in the entrepreneurship process. This calls for further study to examine the perceived social norms-entrepreneurial intention link in a different context. The study was based on an agribusiness context that has so far been ignored despite the hypothetical potential of the agricultural industry to provide jobs to the youths, and to contribute to achieving food security and inclusive economic growth. The study confirmed the existence of the PSN-AI link in the DRC 
context, in that when youths perceive that agribusiness is a socially valued and supported career they become more resilient, with much hope, confidence, and optimism to engage in agribusiness activities. However, the research contributed to the entrepreneurial intention literature by showing that the effect of perceived social norms on the intention to engage in agribusiness is much stronger for urban, male, and more-educated youths, but it is weaker among the youths who would have easier access to farming land. The research also found out that the weak relationship between PSN and EI often reported in previous studies is because the mechanism through which the former shapes the latter has not been thoroughly examined. Thus, this research contributes to the literature by showing that PC serves as one of the mechanisms through which PSN drives AI. The intention of youths to engage in agribusiness increases when their PC improves. These findings contribute to an older, yet not thoroughly understood, TPB in the field of entrepreneurship. The paper has new policy implications because it reveals that providing funds is not enough to promote youth agribusiness if youths' perceptions of social norms about agribusiness, their psychological capital, gender, educational level, location (rural versus urban), and land ownership capacity are not thoroughly considered.

This research suffers from some limitations and offers opportunities for future research questions. This study used cross-sectional data collected on the constructs of the dynamic PC $[25,88]$ as well as AI and PSN [38] constructs. Thus, future studies could use longitudinal data to track the effects of PSN and PC on AI across the youths' life course. Moreover, while the intention is the best predictor of behavior, it is not the behavior itself [20], because the road from intention to action and new venture creation can sometimes be long [101]. Future studies could therefore look closer to the volitional issues [42], namely, which factors influence the transformation of intention into actions. This is still a knowledge gap, and there is an increasing scholarly call to fill it $[15,20]$. The results of the models can suffer from endogeneity, because a significant number of potential AI drivers were not controlled for. Thus, the results cannot be interpreted in the sense of strict causality, and this limitation can be addressed in future research by using experimental or quasiexperimental methods such as propensity score matching, which currently have more success in the area of entrepreneurship. The study's relationships were not explained enough because of the quantitative design. This can be delved into if future research includes a qualitative aspect. Finally, despite the quality of the goodness of fit indicators, we are very cautious in confirming that the model fit is perfect because a comprehensive assessment of these measures has not been conducted so far [97]. Therefore, all of the thresholds and conclusions above should be considered as being very tentative.

Author Contributions: All the authors have made substantial contributions to the research design, data collection, data analysis, and write-up of the manuscript. The submitted version was checked and approved by all the authors. All authors have read and agreed to the published version of the manuscript.

Funding: This research was funded by the International Fund for Agricultural Development (IFAD) under the grant 2000001374 'Enhancing Capacity to Apply Research Evidence (CARE) in Policy for Youth Engagement in Agribusiness and Rural Economic Activities in Africa' Project in the International Institute of Tropical Agriculture (IITA).

Institutional Review Board Statement: Not Applicable.

Informed Consent Statement: Informed consent was obtained from all participants involved in the study.

Data Availability Statement: The data presented in this study are available on request from the corresponding author.

Acknowledgments: The first author is immensely grateful for the generous mentoring support from Förderverein Uni Kinshasa e.V, through the BEBUC Scholarship program. The usual disclaimers apply.

Conflicts of Interest: The authors declare no conflict of interest. 


\section{Appendix A. Agripreneurial Intention Measurement Items}

I am interested in agribusiness as a career option

I wish to venture into agribusiness activities

I desire agribusiness activities

Agribusiness is my passion

I have the intention to engage in agribusiness and agriculture

I have the envy to become an agripreneur

I wish to own an agricultural firm

Farming is my preference among other career options

I am ready to engage in agribusiness

I am committed to launching an agribusiness venture in the future

I have started looking for agribusiness opportunities to exploit soon

The agribusiness career is suitable for me

\section{Appendix B. Perceived Social Norms' Dimensions and Measurement Items}

\begin{tabular}{l} 
Normative Beliefs Items \\
\hline My closest family members think that I should engage in agribusiness \\
My friends think that I should engage in agribusiness \\
People of importance to me think that I should become agripreneur \\
My colleagues are okay with the idea of engaging the agricultural value chain \\
My closest family members would support my idea of venturing into agribusiness \\
My friends would support my decision of becoming agripreneur \\
People of importance to me can support my decision of becoming agripreneur \\
Local financial institutions can fund my would be agribusiness activities \\
The Congolese Government is okay with the idea that people should engage in agribusiness \\
The local community is okay with the idea of engaging in agribusiness \\
The Congolese Government can assist me in my agribusiness endeavors \\
The local community can support my decision to engage in agribusiness \\
People think that the business environment is fair for agribusiness \\
Perceived social valuation items \\
Starting an agribusiness venture is socially desirable \\
I always see information in the media about youth successful agribusiness ventures \\
People who have succeeded in agribusiness are respected in the society \\
In our community, agribusiness is considered a credible career to become rich \\
People in my community think that agripreneurs are competent persons \\
People around me give importance to Agricultural income Generating Activities
\end{tabular}




\section{Appendix C. Psychological Capital's Dimensions and Measurement Items}

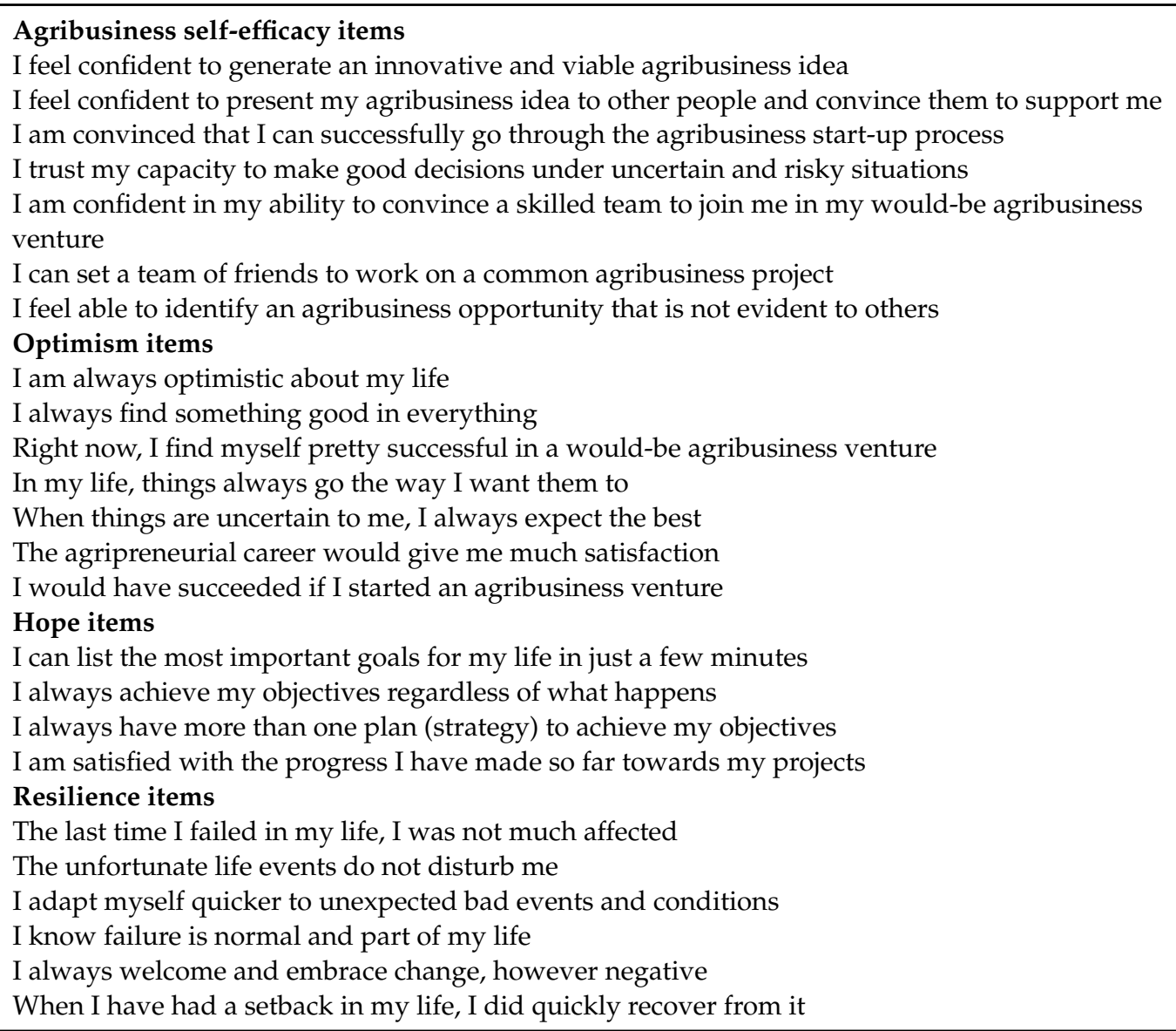

\section{References}

1. Ibrahim Foundation. Africa's Youth: Jobs or Migration? Ibrahim Foundation: London, UK, 2019.

2. Losch, B. Structural transformation to boost youth labour demand in Sub-Sahran Africa: The role of agriculture, rural areas and territorial development. In ILO Employment Policy Department, Employmet Working Paper; ILO: Geneva, Switzerland, 2016; Volume 204, pp. 1-65.

3. Raikes, A.; Yoshikawa, H.; Britto, P.R.; Iruka, I. Children, Youth and Developmental Science in the 2015-2030 Global Sustainable Development Goals. Soc. Policy Rep. 2017, 30, 1-23. [CrossRef]

4. Afere, L.; Oluwaseun, A.; Baker, V.; Barbou, C.; Mabonga, L.; Mabonga, L.; Ocansey, M.; Neate, P. Making Agriculture Attractive to Young People; Technical Brief; Technical Centre for Agricultural and Rural Cooperation-CTA: Herts, UK, 2019; Volume 24, pp. 1-8.

5. Bremner, J. Population and Food Security: Africa's Challenge, Population Reference Bureau; Policy Brief; Population Reference Bureau Policy: Nairobi, Kenya, 2012.

6. Yami, M.; Feleke, S.; Abdoulaye, T.; Alene, A.D.; Bamba, Z.; Manyong, V. African Rural Youth Engagement in Agribusiness: Achievements, Limitations, and Lessons. Sustainability 2019, 11, 185. [CrossRef]

7. Molinario, G.; Hansen, M.C.; Potapov, P.V.; Tyukavina, A.; Stehman, S.; Barker, B.; Humber, M. Quantification of land cover and land use within the rural complex of the Democratic Republic of Congo. Environ. Res. Lett. 2017, 12, 104001. [CrossRef]

8. FAO. Save and Grow Cassava-A Guide to Sustainable Production Intensification; FAO: Rome, Italy, 2013.

9. AFDB; OECD; UNDP. Economic Perspectives in Africa-DRC; OECD: Paris, France, 2017.

10. Kiuma, A.K.; Araar, A.; Kaghoma, C.K. Internal migration and youth entrepreneurship in the Democratic Republic of the Congo. Rev. Dev. Econ. 2020, 1-25. [CrossRef]

11. ILO. World Employment and Social Outlook-Trends 2017; ILO: Geneva, Switzerland, 2017.

12. World Bank. World Bank Group, Country Highlights, Democratic Republic of Congo. Enterprise Survey; World Bank: Washington, DC, USA, 2014; p. 2.

13. Loan, L.T.; Quang, V.; Tuan, D.M.; Nghia, V.T.; Doanh, D.C. Exploring factors affecting entrepreneurial desirability among Vietnam students. Int. J. Data Netw. Sci. 2020, 4, 105-114. [CrossRef]

14. Dissanayake, D. The Impact of perceived desirability and perceived feasibility on entrepreneurial intention among undergraduate students in Sri Lanka: An extended model. Kelaniya J. Manag. 2013, 2, 39-57. [CrossRef] 
15. Liñán, F.; Fayolle, A. A systematic literature review on entrepreneurial intentions: Citation, thematic analyses, and research agenda. Int. Entrep. Manag. J. 2015, 11, 907-933. [CrossRef]

16. Valliere, D.; Gedeon, S.A. Entrepreneurial desirability and intent among youth in Bhutan. J. Int. Bus. Entrep. Dev. 2015, 8, 65. [CrossRef]

17. Ali, A.; Alam, K.; Lodhi, N. Students intentions towards entrepreneurship: Pakistan perspective. NICE Res. J. 2014, 7, 154-176.

18. Buttar, H.M. Retracted: Formation of Entrepreneurial Career Intentions: The Role of Sociocognitive Factors. J. Employ. Couns. 2015, 52, 2-17. [CrossRef]

19. Kailer, N.; Hora, W. Entrepreneurial Intentions and Activities of Students at AUSTRIAN Universities: Global University Entrepreneurial Spirit Students Survey 2016; National Report Austria; Johannes Kepler University: Linz, Austria, 2017.

20. Nabi, G.; Liñán, F.; Fayolle, A.; Krueger, N.; Walmsley, A. The Impact of Entrepreneurship Education in Higher Education: A Systematic Review and Research Agenda. Acad. Manag. Learn. Educ. 2017, 16, 277-299. [CrossRef]

21. Shane, S. Reflections on the 2010 AMR Decade Award: Delivering on the Promise of Entrepreneurship as a Field of Research. Acad. Manag. Rev. 2012, 37, 10-20. [CrossRef]

22. Shapero, A. The Entrepreneurial Event; Kent, C.A., Ed.; Lexington Books: Toronto, ON, Canada, 1984.

23. Barba-Sánchez, V.; Atienza-Sahuquillo, C. Entrepreneurial intention among engineering students: The role of entrepreneurship education. Eur. Res. Manag. Bus. Econ. 2018, 24, 53-61. [CrossRef]

24. Neneh, B.N. From entrepreneurial intentions to behavior: The role of anticipated regret and proactive personality. J. Vocat. Behav. 2019, 112, 311-324. [CrossRef]

25. Sebora, T.C. Psychological Capital and the Entrepreneurial Intention of College Students. Ph.D. Thesis, University of Nebraska, Lincoln, Nebraska, 12 April 2020. Available online: http:/ / www.researchgate.net/publication/257964362 (accessed on 12 April 2020).

26. Zhang, Y.Y.; Duysters, G.G.; Cloodt, M.M. The role of entrepreneurship education as a predictor of university students' entrepreneurial intention. Int. Entrep. Manag. J. 2014, 10, 623-641. [CrossRef]

27. Cheng, L.J.; St. John's University; Liao, C.C. The Drivers of Entrepreneurial Intention: The Role of Social Capital and Overconfidence. Contemp. Manag. Res. 2017, 13, 143-162. [CrossRef]

28. Ajzen, I. Perceived Behavioral Control, Self-Efficacy, Locus of Control, and the Theory of Planned Behavior1. J. Appl. Soc. Psychol. 2002, 32, 665-683. [CrossRef]

29. Conner, M.; Armitage, C.J. Extending the Theory of Planned Behavior: A Review and Avenues for Further Research. J. Appl. Soc. Psychol. 1998, 28, 1429-1464. [CrossRef]

30. Contreras, F.; De Dreu, I.; Espinosa, J.C. Examining the Relationship between Psychological Capital and Entrepreneurial Intention: An Exploratory Study. Asian Soc. Sci. 2017, 13, 80. [CrossRef]

31. Liñán, F. Intention-Based Models of Entrepreneurship Education. Ph.D. Thesis, Department of Applied Economics (Economía Aplicada I), University of Seville, Sevilla, Spain, 2016.

32. Naktiyok, A.; Karabey, C.N.; Gulluce, A.C. Entrepreneurial self-efficacy and entrepreneurial intention: The Turkish case. Int. Entrep. Manag. J. 2009, 6, 419-435. [CrossRef]

33. Gielnik, M.M.; Barabas, S.; Frese, M.; Namatovu-Dawa, R.; Scholz, F.A.; Metzger, J.R.; Walter, T. A temporal analysis of how entrepreneurial goal intentions, positive fantasies, and action planning affect starting a new venture and when the effects wear off. J. Bus. Ventur. 2014, 29, 755-772. [CrossRef]

34. Tanveer, M.A.; Shafique, O.; Akbar, S.; Rizvi, S. Intention of business graduate and undergraduate to become entrepreneur: A study from Pakistan. J. Basic Appl. Sci. Res. 2013, 3, 718-725.

35. Zeffane, R. Gender and Youth Entrepreneurial Potential: Evidence from the United Arab Emirates. Int. J. Bus. Manag. 2012, 8, 60. [CrossRef]

36. Shinnar, R.S.; Giacomin, O.; Janssen, F. Entrepreneurial Perceptions and Intentions: The Role of Gender and Culture. Entrep. Theory Pract. 2012, 36, 465-493. [CrossRef]

37. Sultan, J. Entrepreneurial intention among undergraduate agricultural students in Ethiopia: The case of Jimma University. Afr. J. Bus. Manag. 2017, 11, 293-303. [CrossRef]

38. Ephrem, A.N.; Namatovu, R.; Basalirwa, E.M. Perceived social norms, psychological capital and entrepreneurial intention among undergraduate students in Bukavu. Educ. Train. 2019, 61, 963-983. [CrossRef]

39. Bae, T.J.; Qian, S.; Miao, C.; Fiet, J.O. The Relationship Between Entrepreneurship Education and Entrepreneurial Intentions: A Meta-Analytic Review. Entrep. Theory Pract. 2014, 38, 217-254. [CrossRef]

40. Byabashaija, W.; Katono, I. The impact of college entrepreneurial education on entrepreneurial attitudes and intention to start a business in Uganda. J. Dev. Entrep. 2011, 16, 127-144. [CrossRef]

41. Johnmark, D.R.; Munene, J.C.; Balunywa, W.; Nisar, T. Robustness of personal initiative in moderating entrepreneurial intentions and actions of disabled students. Cogent Bus. Manag. 2016, 3, 1-16. [CrossRef]

42. Solesvik, M. A Study of Personal Initiative as a Mediator between Self-efficacy and Entrepreneurial Intentions. Acad. Manag. Proc. 2017, 2017, 15614. [CrossRef]

43. Mehlhorn, J.E.; Bonney, L.; Fraser, N.; Miles, M.P. Benchmarking entrepreneurship education in U.S., Australian, and New Zealand University agriculture programs. J. Dev. Entrep. 2015, 20, 1-14. [CrossRef] 
44. Haque, R.; Kabir, Z.; Rahman, M.; Chowdhury, S.P.; Islam, S. Entrepreneurial Intentions: A Study on Students from Countryside University. Asian Econ. Financ. Rev. 2017, 7, 972-980. [CrossRef]

45. Santos, F.J.; Roomi, M.A.; Liñán, F. About Gender Differences and the Social Environment in the Development of Entrepreneurial Intentions. J. Small Bus. Manag. 2016, 54, 49-66. [CrossRef]

46. Kautonen, T.; Van Gelderen, M.; Fink, M. Robustness of the Theory of Planned Behavior in Predicting Entrepreneurial Intentions and Actions. Entrep. Theory Pract. 2013, 39, 655-674. [CrossRef]

47. Robledo, J.L.R.; Arán, M.V.; Sanchez, V.M.; Molina, M.; Ángel, R. The moderating role of gender on entrepreneurial intentions: A TPB perspective. Intang. Cap. 2015, 11, 92-117. [CrossRef]

48. Iakovleva, T.; Kolvereid, L.; Stephan, U. Entrepreneurial intentions in developing and developed countries. Educ. Train. 2011, 53, 353-370. [CrossRef]

49. Baron, R.A.; Franklin, R.J.; Hmieleski, K.M. Why entrepreneurs often experience low, not high levels of stress: The joint effects of selection and psychological capital. J. Manag. 2016, 42, 742-768. [CrossRef]

50. Silva, J.L.D. A Review of Contract Farming and Factors that Impinge Youths Acceptance to Contract Farming. Eur. J. Soc. Sci. 2009, 11, 328-338.

51. Hsu, S.-H.; Wang, Y.-C.; Chen, Y.-F.; Dahlgaard-Park, S.M. Building business excellence through psychological capital. Total. Qual. Manag. Bus. Excel. 2014, 25, 1210-1223. [CrossRef]

52. Kangarlouei, S.J.; Shadkami, N.; Motavassel, M. The Impact of Intellectual Capital, social capital and psychological capital on Competitive advantage of Vehicle Industries in Tehran Stock Exchange (TSE). Int. J. Acad. Res. Bus. Soc. Sci. 2012, 2, 559-566.

53. Wernsing, T. Psychological Capital: A test of measurement invariance across 12 national cultures. J. Leadersh. Organ. Stud. 2013, 21, 179-190. [CrossRef]

54. Peprah, W.K.; Abandoh-sam, J.A. Entrepreneurship is an Attitude: A Case study of Students of Valley View University. Int. J. Bus. Manag. 2017, 5, 2015-2018.

55. Luthans, F. Organizational Behavior: An Evidence-Based Approach, 12th ed.; McGraw-Hill: New York, NY, USA, 2011.

56. Hmieleski, K.M.; Carr, J.C. The relationship between entrepreneur psychological capital and new venture performance. Front. Entrep. Res. J. 2008, 28, 1-15.

57. Ahaibwe, G.; Mbowa, S.; Lwanga, M.M. Youth Engagement in Agriculture in Uganda: Challenges and Prospects; Economic Policy Research Centre (EPRC): Kampala, Uganda, 2013; p. 106.

58. IITA. ENABLE Youth: Ensuring the Success of Youth in Agribusiness; The IITA Bulletin: Ibadan, Nigeria, April 2016; Volume 2322, p. 5 .

59. Moitui, J. Challenges and Opportunities in Agriculture for African Youth 24; CTA Technical Brief; Technical Centre for Agricultural and Rural Cooperation: Herts, UK, 2019; Volume 24, pp. 1-8.

60. Branch, A.K.; Rahimian, P. The study of barriers to entrepreneurship in men and women. Aust. J. Bus. Manag. Res. 2011, 1, 31-36.

61. Sandhu, M.S.; Sidique, S.F.; Riaz, S. Entrepreneurship barriers and entrepreneurial inclination among Malaysian postgraduate students. Int. J. Entrep. Behav. Res. 2011, 17, 428-449. [CrossRef]

62. White, B. Agriculture and the Generation Problem: Rural Youth, Employment and the Future of Farming. IDS Bull. 2012, 43, 9-19. [CrossRef]

63. Díaz-García, M.C.; Jiménez-Moreno, J. Entrepreneurial intention: The role of gender. Int. Entrep. Manag. J. 2009, 6, 261-283. [CrossRef]

64. Fisher, G. Effectuation, Causation, and Bricolage: A Behavioral Comparison of Emerging Theories in Entrepreneurship Research. Entrep. Theory Pract. 2012, 36, 1019-1051. [CrossRef]

65. Baker, T.; Nelson, R.E. Creating Something from Nothing: Resource Construction through Entrepreneurial Bricolage. Adm. Sci. Q. 2005, 50, 329-366. [CrossRef]

66. Sarasvathy, S.D. Causation and Effectuation: Toward a Theoretical Shift from Economic inevitability to Entrepreneurial contigency. Acad. Manag. Rev. 2001, 26, 243-263. [CrossRef]

67. Smith, D.J.; Blundel, R.K. Improvisation and Entrepreneurial Bricolage versus Rationalisation: A case-based analysis of contrasting responses to economic instability in the UK brass musical instruments industry. J. Gen. Manag. 2014, 40, 53-78. [CrossRef]

68. Fatoki, O.O.; Chindoga, L. An investigation into the obstacles to youth entrepreneurship in South Africa. Int. Bus. Res. 2011, 4, 161. [CrossRef]

69. Joseph, I. Factors Influencing International Student Entrepreneurial Intention in Malaysia. Am. J. Ind. Bus. Manag. 2017, 7, 424-428. [CrossRef]

70. Shirokova, G.; Tsukanova, T.; Morris, M.H. The Moderating Role of National Culture in the Relationship Between University Entrepreneurship Offerings and Student Start-Up Activity: An Embeddedness Perspective. J. Small Bus. Manag. 2017, 56, 103-130. [CrossRef]

71. Anwarudin, O. The Interest and Action of Young Agricultural Entrepreneur on Agribusiness in Cianjur Regency, West Java. J. Penyul. 2018, 14, 189-198.

72. Ganpat, W.G.; Webster, N. An Agricultural Apprenticeship Program for Youth in Trinidad, West Indies: Can it Meet the Caribbean's Urgent Need for Younger Farmers? J. Youth Dev. 2010, 5, 40-51. [CrossRef]

73. Poggesi, S.; Mari, M.; De Vita, L. What's new in female entrepreneurship research? Answers from the literature. Int. Entrep. Manag. J. 2016, 12, 735-764. [CrossRef] 
74. Westhead, P.; Solesvik, M.Z. Entrepreneurship education and entrepreneurial intention: Do female students benefit? Int. Small Bus. J. Res. Entrep. 2016, 34, 979-1003. [CrossRef]

75. Nnanna, M.A.; Nwankwo, E.E.; Anyanwu, C.I. Determinants of agricultural labour participation among youths in Abia state, Nigeria. Int. J. Food Agric. Econ. 2012, 2, 157-164.

76. Davis, A. Rural and urban women entrepreneurs: A comparison of service needs and delivery methods priorities. Int. J. Bus. Sci. Appl. Manag. 2011, 6, 1-16.

77. Zakaria, H.; Adam, H.; Abujaja, A.M. Assessment of agricultural students of university for development studies intention to take up self- employment in agribusiness. Int. J. Inf. Technol. Bus. Manag. 2014, 21, 53-67.

78. Rim, J.; Nsanganira, T. Creating jobs for rural youth in agricultural value chains 20. In Technical Centre for Agricultural and Rural Cooperation-CTA Technical Brief; CTA Publications: Herts, UK, 2019.

79. Hamida, S. Perception of Final Year Undergraduate Students of Agriculture at the University of Ghana on Self-Employment in Agribusiness. Ph.D. Thesis, University of Ghana, Accra, Ghana, 2017.

80. Leavy, J.; Hossain, N. Who Wants to Farm? Youth Aspirations, Opportunities and Rising Food Prices. IDS Work. Pap. 2014, 2014. [CrossRef]

81. Ojebiyi, W.G.; Ashimolowo, O.R.; Odediran, O.F.S.; Oetan, O.S.; Aromiwura, O.A.; Adeoye, A.S. Willingness to venture into agriculture-related Enterprises after Graduation among final year agriculture students of Federal University of Agriculture, Abeokuta. Int. J. Appl. Agric. Apic. Res. 2015, 11, 103-114.

82. Chinsinga, B.; Chasukwa, M. Youth, Agriculture and Land Grabs in Malawi. IDS Bull. 2012, 43, 67-77. [CrossRef]

83. Gyimah-brempong, K.; Kimenyi, M.S. Youth Policy and the Future of African Development; Brookings Institution: Washington, DC, USA, 2013.

84. Chua, H.S.; Bedford, O. A Qualitative Exploration of Fear of Failure and Entrepreneurial Intent in Singapore. J. Career Dev. 2015, 43, 319-334. [CrossRef]

85. Saunders, M.; Lewis, P.; Thornhill, A. Research Methods for Business Students, 3rd ed.; Prentice Hall: Upper Saddle River, NJ, USA, 2003.

86. Babin, B.J.; Svensson, G. Structural equation modeling in social science research: Issues of validity and reliability in the research process. Eur. Bus. Rev. 2012, 24, 320-330. [CrossRef]

87. Esfandiar, K.; Sharifi-Tehrani, M.; Pratt, S.; Altinay, L. Understanding entrepreneurial intentions: A developed integrated structural model approach. J. Bus. Res. 2019, 94, 172-182. [CrossRef]

88. Siu, O.L.; Bakker, A.B.; Jiang, X. Psychological Capital Among University Students: Relationships with Study Engagement and Intrinsic Motivation. J. Happiness Stud. 2014, 15, 979-994. [CrossRef]

89. Wang, X.; Zheng, Q.; Cao, X. Psychological capital: A new perspective for psychological Health Education Management of Public Schools. Public Pers. Manag. 2014, 43, 371-383. [CrossRef]

90. Chumney, F.L. Structural Equation Models with Small Samples: A Comparative Study of Four Approaches. Ph.D. Thesis, University of Nebraska, Lincoln, Nebraska, 2013.

91. Fairchild, A.J.; McDaniel, H.L. Best (but oft-forgotten) practices: Mediation analysis. Am. J. Clin. Nutr. 2017, $105,1259-1271$. [CrossRef] [PubMed]

92. Hair, J.F.; Sarstedt, M.; Ringle, C.M.; Mena, J.A. An assessment of the use of partial least squares structural equation modeling in marketing research. J. Acad. Mark. Sci. 2012, 40, 414-433. [CrossRef]

93. Quan, L.; Huy, H. The Effect of Entrepreneurial Human Capital and Entrepreneurial Failure Learning on the Entrepreneurial Restart Intention. Asian Soc. Sci. 2014, 10, 99. [CrossRef]

94. Saeid, K.; Harm, B.; Thomas, L.; Zahra, A.; Mohammad, C.; Martin, M. Application of Structural Equation Modelling to assess the effect of entrepreneurial characteristics on students' entrepreneurial Intention. In Proceedings of the 6th European Conference on Entrepreneurship and Innovation, Aberdeen, UK, 15-16 September 2011; pp. 954-967.

95. Ali, F.; Rasoolimanesh, S.M.; Sarstedt, M.; Ringle, C.M.; Ryu, K. An assessment of the use of partial least squares structural equation modeling (PLS-SEM) in hospitality research. Int. J. Contemp. Hosp. Manag. 2018, 30, 514-538. [CrossRef]

96. Obschonka, M.; Silbereisen, R.K.; Schmitt-Rodermund, E. Entrepreneurial intention as developmental outcome. J. Vocat. Behav. 2010, 77, 63-72. [CrossRef]

97. Hair, J.F.; Risher, J.J.; Sarstedt, M.; Ringle, C.M. When to use and how to report the results of PLS-SEM. Eur. Bus. Rev. 2019, 31, 2-24. [CrossRef]

98. Dawson, J.F. Moderation in Management Research: What, Why, When, and How. J. Bus. Psychol. 2014, 29, 1-19. [CrossRef]

99. Eberhard, B. Smart work: The transformation of the labour market due to the fourth industrial revolution. Int. J. Bus. Econ. Sci. Appl. Res. 2017, 10, 47-66.

100. Naudé, W. Entrepreneurship, Education and the Fourth Industrial Revolution in Africa; IZA: Bonn, Germany, 2017.

101. Gielnik, M.M.; Frese, M.; Kahara-Kawuki, A.; Katono, I.W.; Kyejjusa, S.; Ngoma, M.; Munene, J.C.; Namatovu-Dawa, R.; Nansubuga, F.; A Orobia, L.; et al. Action and Action-Regulation in Entrepreneurship: Evaluating a Student Training for Promoting Entrepreneurship. Acad. Manag. Learn. Educ. 2015, 14, 69-94. [CrossRef] 
102. Newman, A.; Ucbasaran, D.; Zhu, F.; Hirst, G. Psychological capital: A review and synthesis. J. Organ. Behav. 2014, 35, S120-S138. [CrossRef]

103. Al-Jubari, I.; Hassan, A.; Liñán, F. Entrepreneurial intention among University students in Malaysia: Integrating self-determination theory and the theory of planned behavior. Int. Entrep. Manag. J. 2018, 15, 1323-1342. [CrossRef] 